\title{
Ambalaj Atığı Toplama Sistemlerinin Karşılaştırmalı Sürdürülebilirlik Analizi
}

\author{
Comparative Sustainability Analysis of Packaging Waste Collection Systems
}

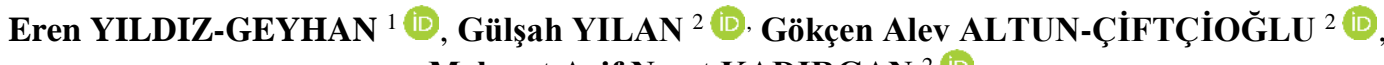 \\ Mehmet Arif Neşet KADIRGAN ${ }^{2}$ (iD \\ ${ }^{1}$ Maltepe Belediyesi Çevre Koruma ve Kontrol Müdürlüğ̈̈, 34843, Maltepe/İstanbul \\ ${ }^{2}$ Marmara Üniversitesi Kimya Mühendisliği Bölümü̈, 34722, Göztepe/İstanbul
}

\begin{abstract}
Öz
Ambalaj atıklarının geri dönüşümü hem ekonomik hem de çevresel avantajlarından dolayı hızla artan atık üretimine karşı alınacak önlemleri destekleyebilecek önemli bir çalışma alanıdır. Maltepe Belediyesi ile ortaklaşa yürütülen bu çalışma; çevresel, sosyal ve ekonomik açıdan en uygun olan ambalaj atı̆̆ toplama sisteminin geliştirilmesini amaçlamaktadır. Bu kapsamda; mevcut ambalaj atığı toplama sistemi ve bu sisteme alternatif olarak geliştirilen 6 farklı toplama sistemi incelenmiştir. Toplama sistemlerinin sürdürülebilirlik analizinde yaşam döngüsü değerlendirmesi metodu kullanılmıştır. Yaşam döngüsü değerlendirmesinde kullanılacak olan envanter verileri; mevcut sistem analizi, saha gözlemi, anketler ve alternatif sistem hesaplamaları sonucunda elde edilmiştir. Alternatif senaryoların çevresel ve ekonomik analizi mevcut sistem verileri dikkate alınarak hesaplanırken; sosyal analiz, saha gözlemleri ve anketlere dayandırılarak yapılmıştır. Bu çalışmanın sonunda, çevresel ve ekonomik açıdan değerlendirme yapıldığında resmi toplama sistemine kıyasla, kayıt dışı toplama sisteminin daha avantajlı olduğu görülmüştür. Ancak sosyal analiz sonuçları irdelendiğinde kontrolsüz toplama sistemlerinin ciddi bir dezavantaja sahip olduğu tespit edilmiş, bütünleyici bir bakış açısına ihtiyaç olduğu açıkça görülmüştür. Bütüncül bir perspektifle yürütülen çevresel, sosyal ve ekonomik analiz neticesinde ortaya çıkarılan zayıflıkların, resmi ve kayıt dışı sistem entegrasyonunun önerildiği alternatif toplama sistemiyle minimize edilebileceği öngörülmüştür.
\end{abstract}

Anahtar Kelimeler: Yaşam döngüsü değerlendirmesi, ambalaj atığı, sürdürülebilirlik analizi, vaka analizi

\begin{abstract}
Packaging waste recycling is a vital research area since it bears both economic and environmental advantages to support the measures against the exponential generation of waste. This study aims to develop an environmentally, socially, and economically optimum packaging waste collection system. Within this context, the existing packaging waste collection system and 6 different alternative systems are analyzed. In the sustainability analysis of the collection system, life cycle assessment methodology is used. Inventory data required for life cycle assessment is based on the existing system analysis, site observation, questionnaires and alternative system calculations. Whereas environmental and economic analysis of alternative system calculations is based on the existing system data; inventory data of social analysis is extracted from site observations and questionnaires. The results of this study show that the informal system is environmentally and economically more beneficial than the formal system. On the other hand, social analysis results show that the informal systems have substantial disadvantages, highlighting the need for a complementary perspective. From a holistic point of view, the weaknesses pointed out via environmental, social and economic analysis could be minimized with different alternative integrated system applications.

Keywords: life cycle assessment, packaging waste, sustainability analysis, case study
\end{abstract}

\section{GíRiş}

Ülkemizde ambalaj atıkları ile ilgili ilk hukuksal adım, hâlihazırda yürürlükte olmayan 14.03.1991 tarihli 20814 sayılı resmi gazetede yayınlanan Katı Atıkların Kontrolü Yönetmeliği ile atılmıştır [1]. 2004 y1lında "Ambalaj Atıklarının Kontrolü Yönetmeliği”” yayınlandıktan sonra özellikle yerel yönetimler, geri dönüştürülebilir ambalaj atıklarının yönetiminden sorumlu olmuşlardır. Ancak Avrupa Birliği uyum çalışmaları kapsamında değerlendirilen ve yayınlanan bu yönetmelikler uygulamada ülkemiz koşulları ile entegrasyon sorunu yaşamaktadır. Ambalaj atıkları yönetmeliği ilk yayınlandığı 2004 yılından sonra 2007, 2011 ve 2017 yıllarında revize edilmiştir [2-5]. Bunların dışında yine ambalaj atıklarının yönetimini direkt olarak etkileyen Atık Getirme Merkezi Tebliği 31.12.2014 ve Sıfır Atık Yönetmeliği 12.07.2019 tarihinde yayınlanmış ve sistemin işleyişi ile ilgili uygulama değişiklikleri yürürlüğe konulmuştur $[6,7]$.

İlgili yönetmeliklerle, ambalaj atıklarının toplama sorumluluğu yerel yönetimlere verilmiştir [5]. Yerel yönetimler, kendi koşullarına göre geliştirdikleri toplama - taşıma modelleriyle ambalaj atıklarının yönetimini sağlamaktadır. 
Ancak, yasal sorumluluklar ve yükümlülükler temel alınarak yerel yönetimlerce yapılan toplama çalışmalarının dışında, "sokak toplayıcısı" olarak adlandırılan kişiler tarafından da kayıt dışı olarak toplama yapıldığı ve sokak toplayıcıları tarafindan toplanan ambalaj atığı miktarının yerel yönetimler tarafından toplanan miktara göre çok daha fazla olduğu bilinmektedir [8].

Ambalaj atıklarının geri dönüştürülerek üretim sistemine kazandırılması, birincil kaynakların tüketimi ve konvansiyonel atık bertarafının çevresel etkileri düşünüldüğünde hem ekonomik hem de çevresel olarak avantajlıdır. Özellikle ekonomik faydalarından ötürü, sorumlu kurum ve kuruluşlar genel olarak toplanan atık miktarını arttırmaya odaklanmıştır. Ancak bu yaklaşım sürdürülebilirlik açısından ele alındığında eksik kalmaktadır. Çevresel ve ekonomik olgular 3 boyutlu sürdürülebilirlik kavramının sadece 2 boyutunu oluşturmaktadır. Sistemlerin sürdürülebilirliği insan olgusundan ayrı tutulamayacağından dolayı, çevresel, sosyal ve ekonomik etkiler bütüncül bir yaklaşımla incelenmelidir.

Son yıllarda, birçok araştırmacı atık yönetim sistemlerinin yaşam döngüsü değerlendirmesi (YDD) çalışmalarına odaklanmıştır. Literatür çalışmaları incelendiğinde, özellikle Çevresel Yaşam Döngüsü Değerlendirmesi (Ç-YDD) üzerine birçok çalışma göze çarpmaktadır. Örneğin, Laurent ve ark. [9] yapmış oldukları derleme araştırmasında katı atık yönetim sistemleri konusunda yapılan 222 adet Ç-YDD çalışmasını listelemişlerdir. $\mathrm{Bu}$ çalışmalar arasında, özellikle geri dönüştürülebilir atıkların Ç-YDD analizleri de mevcuttur [10-15]. Bunların dışında Türkiye'de yapılan araştırmalara bakıldığında; çeşitli araştırmacıların [16-20] atık yönetim sistemleri konusunda çalıştıkları görülmüştür. Diğer taraftan literatürdeki Sosyal Yaşam Döngüsü Değerlendirmesi (S-YDD) çalışmaları incelendiğinde; atık yönetim araştırmalarının sınırlı sayıda olduğu görülmüştür [2128]. Bu çalışmalardan bazıları ambalaj atığı toplama sistemlerinin sosyal analizini maliyet bazlı incelerken $[21,24]$, bazıları da ambalaj atığı toplama ve ayırma sistemlerinin sosyal analizini boyutsuz incelemişlerdir [25-28]. Ambalaj atıklarının farklı toplanma sistemlerinin ekonomik analizine ait literatürde birçok çalışma olmakla birlikte [29-32]; Ekonomik Yaşam Döngüsü Değerlendirmesi (E-YDD) üzerine sınırlı sayıda çalışma olduğu görülmektedir [11, 21, 33-35] .

Yukarıda bahsedilen çalışmalardan da anlaşıldığı gibi atık yönetim sistemlerinin yaşam döngüsü analizleri çoğunlukla tek bir açıdan değerlendirilerek yapılmıştır. Ancak daha önce de belirtildiği gibi, sistemlerin pozitif ve negatif etkilerini bütüncül bir şekilde görebilmek için kapsamlı bir sürdürülebilirlik analizinin yapılması önemli ve gereklidir. Bu bağlamda, ilk olarak Klöpffer [36] tarafindan geliştirilen Sürdürülebilir Yaşam Döngüsü Değerlendirmesi (SYDD) tekniği; çevresel, sosyal ve ekonomik YDD tekniklerini birleştirmekte ve temsilci bir tekil skor elde edilmesini sağlamaktadır. Literatür çalışmaları incelendiğinde; farklı konularda SYDD çalışmaları görülmekle beraber [37-42], geri dönüştürülebilir ambalaj atıklarının sürdürülebilirlik analizi üzerine bir çalışmaya rastlanmamıştır.

Bu çalışma ile Türkiye'de ilk olarak ambalaj atıklarının toplanmasında çevresel, sosyal ve ekonomik olarak sürdürülebilir bir ambalaj atığı toplama sisteminin geliştirilmesi hedeflenmiştir. $\mathrm{Bu}$ amaçla, İstanbul Maltepe bölgesi pilot ölçek olarak belirlenmiş; uygulanan mevcut ambalaj atığ 1 toplama sistemi ve bu sisteme alternatif olarak geliştirilen sistemler incelenmiş ve çevresel - sosyal - ekonomik analizlerin entegre edildiği bir sürdürülebilir yaşam döngüsü değerlendirmesi yapılmıştır.

\section{MATERYAL VE YÖNTEM}

Bu çalışmada, SYDD'nin yapılması için analiz metodu olarak YDD yaklaşımı kullanılmıştır. SYDD'nin her bir bileşeninin (çevresel, sosyal ve ekonomik) etki analizleri birbirinden bağımsız olarak irdelenmiştir. Elde edilen analiz sonuçlarının birbirine entegre edilip SYDD sonuçlarının bulunması için normalizasyon ve ağırlıklandırma yapılmıştır. Çevresel, sosyal ve ekonomik analizler ISO 14040 ve ISO 14044 standartlarında $[43,44]$ belirtildiği gibi, amaç-kapsam, envanter analizi, etki değerlendirilmesi ve yorumlama olmak üzere 4 temel aşamadan oluşmaktadır.

\subsection{Amaç ve Kapsam}

$\mathrm{Bu}$ çalışmanın temel amacı farklı ambalaj atıkları toplama sistemlerinin çevresel, sosyal ve ekonomik boyutlar dikkate alınarak birbiriyle kıyaslanması ve sürdürülebilirlik analizlerinin yapılmasıdır. Ambalaj atığı toplama sistemlerinin bütüncül bir yaklaşımla irdelenmesi ve elde edilen sonuçların karar verici mercilere yol gösterici nitelikte olması amaçlanmıştır.

Çalışma, yukarıda belirlenen amaç ve kapsama bağlı olarak çevresel, sosyal ve ekonomik olmak üzere 3 bölümde incelenmiştir.

Sistem sınırları geri dönüştürülebilir ambalaj atığının kaynağında karışık atıklardan ayrı depolanması, toplanması, taşınması, ayrıştırılması ve geri dönüşüm tesislerine iletilmesi süreçlerini içermektedir. Fonksiyonel birim olarak, seçilen pilot bölgede (İstanbul-Maltepe), ilgili kurumlar ve/veya kişiler tarafından 1 yılda toplanan toplam karışık ambalaj atığı miktarı belirlenmiştir. Temel olarak 2016 yılı seçilmiş öncelikle çevresel etkiler hesaplanmış, sonrasında daha detaylı bir model kurulması amaciyla bu modele aynı y1l göz önünde bulundurularak sosyal ve ekonomik etkiler de çalışılmıştır.

Sistem sınırları dahilindeki envanter araştırmasına, depolama materyallerinin türleri-miktarları, depolanan atıkların taşınması için kullanılan araçlar, gidilen 
mesafe, yakıt türü-miktarı, ayrıştırma tesisinde kullanılan elektrik, su, yakit giderleri ve geri dönüştürülen malzemeden elde edilen faydalı ürün verileri dahil edilmiştir.

Karşılaştırmalı senaryo analizinin yapılabilmesi için, öncelikli olarak mevcut sistem ve bu sisteme alternatif olabilecek sistem tanımlamaları yapılmıştır. Alternatif senaryolar, ambalaj atıklarının türlerine göre kaynağında ayrıştırılma (ayrıştırma sistemi modellemesi), kaynağında ayrıştırıldıktan sonra farklı materyallerde depolanma (depolama sistemi modellemesi) ve depolanan atıkların farklı toplama sistemleriyle toplanmasina (toplama sistemi modellenmesi) göre modellenmiştir.

Ayrıştırma sistemine göre modelleme yapıldı̆̆ında; ayrıştırmasız sistem (i), 2'li ayrıştırma (ii), 3'lü ayrıştırma (iii) şeklinde 3 farklı sistem öngörülmüştür. Ayrıştırmasız sistemde (i), ambalaj atıkları kaynağında çöplerden ayrıştırılmayıp karışık olarak depolama materyalinde depolanmaktadır. 2'li ayrıştırma sisteminde (ii), ambalaj atıkları 2 farklı fraksiyonda ayrıştırılıp (plastik-metal-kâğıt-karton ve cam) 2 farklı depolama materyalinde depolanmaktadır. 3'lü ayrıştırma sisteminde ise, kâğıt-karton, plastik-metal ve cam şeklinde 3 farklı fraksiyonda atık ayrıştırması yapılmakta ve kaynağında ayrıştırılan atıklar fraksiyonlarına göre 3 farklı materyalde depolanmaktadır. Ayrıştırma sistemi modellemesi, atıkların birbiriyle teması sonucundaki fire oran1, toplama materyali miktarı, vatandaşın katılım oranı, ayrıştırılmış ve ayrıştırılmamış atıkların toplama, depolama, ayrıştırma etkileri düşünülerek farklılaştırılmıştır.

Depolama sistemine göre modelleme yapıldı̆̆ında; ambalaj atıklarının toplanması 4 farklı şekilde incelenir: (i) poşette depolama, (ii) konteynerde depolama, (iii) kumbarada depolama ve (iv) çöp konteynerinde depolama (ayrıştırmasız depolama). Poşette depolama sisteminde, sisteme dâhil olan vatandaşlar geri dönüştürülebilir atıklarını plastik poşetlerde depolayarak kapılarının önünde biriktirmektedir. Kaynağında ayrıştırılan bu atıklar, resmi kurumlar tarafindan önceden belirlenen günlerde bu noktalardan toplanmaktadır. Konteynır ve kumbarada depolama sisteminde ise, depolama materyalleri belirli aralıklarla - konteynırlar için 50$100 \mathrm{~m}$, kumbaralar için 500-1000m - sokak ve caddelere yerleştirilmiştir. Vatandaşlar geri dönüştürülebilir ambalaj atıklarını ayrıştırdıktan sonra kendi imkânlarıyla taşıyarak bu noktalardaki depolama materyallerine atmaktadır. Son depolama sistem önerisi olan çöp konteynerinde depolamada ise, atıklar kaynağında hiçbir şekilde ayrıştırılmamakta, geri dönüştürülemeyen atıklarla birlikte karışık olarak çöp konteynerlerine atılmaktadir. $\mathrm{Bu}$ sistemde ambalaj atıkları, çöp konteynerlerinden sokak toplayıcıları tarafından ayrıştırılmaktadır. Depolama sistemine göre modelleme yapılırken Yıldız-Geyhan ve ark. [20] yapmış olduğu çalışmadaki veriler temel alınmış ve modeller arasındaki farklılıkların toplama materyallerinin niteliği - niceliği ve depolama noktaları arasındaki mesafe farklılıkları olarak öngörülmüştür. Poşette depolama sisteminde kullanılan poşetler tek kullanımlıktır ve her kullanımda vatandaşın kendisi veya ilgili toplayıcı kurum tarafindan temin edilmektedir. Diğer taraftan konteyner ve kumbara ile depolama sisteminde kullanilan depolama materyalleri uzun ömürlüdür ve ilgili kurumlar tarafından temin edilerek sokaklara yerleştirilmektedir. Kısa ömürlü ve uzun ömürlü materyallerin kullanımı hem çevresel hem de ekonomik ektiye sahip olmasından ötürü, depolama sistemi bir modelleme kriteri olarak değerlendirilmiştir. Benzer şekilde, depolama materyallerinin konutlara olan mesafesinin ise vatandaşın geri dönüşüm sistemine katılımındaki gönüllülüğü ve dolayısıyla ayrıştırılan malzeme miktarını etkilediği öngörülmüştür.

Toplama sistemine göre modelleme yapıldı̆̆ında; ambalaj atıklarının toplanması 3 farklı sistemde incelenir: (i) resmi (yetkilendirilmiş kurum), (ii) kayıt dışı (sokak toplayıcıları) ve (iii) entegre sistemler. Yetkilendirilmiş kurumlarca yapılan toplama sistemi, atıkların özel atık toplama araçlarıyla toplandığı, çalışanların iş sağlığı güvenliği koşullarının sağlandığı, her türlü sosyal ve yasal haklarının karşılandığı sistemler olarak öngörülmüştür. Sokak toplayıcıları tarafindan yürütülen toplama sistemi ise kayıt dışı bir sistem olduğu, çalışanların yasal ve sosyal haklarının sağlanmadığ 1 , iş sağlığı güvenliği koşullarının yetersiz olduğu sistemler olarak öngörülmüştür. Üçüncü ve son toplama sistemi senaryosu ise sokak toplayıcıları ve yetkilendirilmiş kurumlarca yürütülen sistemlerin entegre edilmiş şekli olarak öngörülmüştür. Entegre sistemde sokak toplayıcılarının çalışma koşullarının iyileştirilerek resmi sisteme tam (sokak toplayıcılarının tamamının entegre edildiği) ve kısmi (sokak toplayıcılarının \%50'sinin entegre edildiği) olarak iki farklı şekilde entegre edildikleri öngörüsü yapılmıştır. Entegre sistemlerde çalışan personellerin sosyal ve yasal haklarının karşılandığı kabul edilmiştir.

Ayrıştırma ve toplama modelleri temelinde geliştirilen alternatif sistemler ve mevcut sisteme ait senaryolar Tablo 1'de özetlenmiştir. 
Tablo 1. Mevcut durum ve alternatif senaryo modelleri için sistem özellikleri

\begin{tabular}{|c|c|c|c|c|}
\hline Senaryolar & Atık fraksiyonu & Ayrıştırma şekli & Depolama şekli & Toplama Şekli \\
\hline \multirow{2}{*}{$\begin{array}{l}\text { Mevcut } \\
\text { Sistem }\end{array}$} & $\begin{array}{l}\text { Karışık Ambalaj } \\
\text { Cam }\end{array}$ & 2’li ayrıştırma & $\begin{array}{l}\text { Karışık ambalaj: Poşet } \\
\text { Cam: Kumbara }\end{array}$ & Yetkilendirilmiş kurum \\
\hline & $\begin{array}{l}\text { Çöple karıssık } \\
\text { ambalaj }\end{array}$ & Ayrıştırma yok & Çöp konteyneri & Sokak toplayıcıları \\
\hline Senaryo 1 & $\begin{array}{l}\text { Kâğıt-karton } \\
\text { Metal-plastik } \\
\text { Cam }\end{array}$ & 3'lü ayrıştırma & $\begin{array}{l}\text { Kâğıt-karton: Poşet } \\
\text { Metal-plastik: Poşet } \\
\text { Cam: Poşet }\end{array}$ & Yetkilendirilmiş kurum \\
\hline Senaryo 2 & $\begin{array}{l}\text { Kâğğt-karton } \\
\text { Metal-plastik } \\
\text { Cam }\end{array}$ & 3'lü ayrıştırma & $\begin{array}{l}\text { Kâğıt-karton: Konteyner } \\
\text { Metal-plastik: Konteyner } \\
\text { Cam: Konteyner }\end{array}$ & Yetkilendirilmiş kurum \\
\hline Senaryo 3 & $\begin{array}{l}\text { Karışık Ambalaj } \\
\text { Cam }\end{array}$ & 2'li ayrıştırma & $\begin{array}{c}\text { Karışık Ambalaj: } \\
\text { Kumbara } \\
\text { Cam: Kumbara }\end{array}$ & Yetkilendirilmiş kurum \\
\hline Senaryo 4 & $\begin{array}{c}\text { Çöple karışık } \\
\text { ambalaj }\end{array}$ & Ayrıştırma yok & Çöp konteyneri & Sokak toplayıciları \\
\hline \multirow{2}{*}{ Senaryo 5} & Karışık Ambalaj & \multirow{2}{*}{ 2’li ayrıştırma } & Çöp konteyneri & Kısmi entegreli sistem \\
\hline & Cam & & Cam: Kumbara & Yetkilendirilmiş kurum \\
\hline Senaryo 6 & $\begin{array}{l}\text { Karışık Ambalaj } \\
\text { Cam }\end{array}$ & 2’li ayrıştırma & $\begin{array}{l}\text { Karışık Ambalaj: } \\
\text { Kumbara } \\
\text { Cam: Kumbara }\end{array}$ & Entegre sistem \\
\hline
\end{tabular}

\subsection{Envanter Analizi}

Envanter analizi çevresel, sosyal ve ekonomik boyutlar için ayrı ayrı yapılmışırı. Çevresel envanter analizinde, öncelikle mevcut durum incelenmiştir. Mevcut durumdaki toplama ve taşıma faaliyetlerinde kullanılan araçlar, materyaller, yakıt türleri, yakıt tüketim miktarları, ulaşım mesafeleri, su ve elektrik tüketim verileri çevresel envanter analizinin oluşturulması için kullanılmıştır. Buradaki veriler temel alınarak alternatif senaryolara ait envanterlerin hesaplanmasında YıldızGeyhan ve diğ. [20] tarafından geliştirilen metodoloji kullanılmıştır. ÇYDD çalışmalarında kullanılan envanter verileri de Yıldız-Geyhan ve diğ. [28]'den alınmıştır.

Sosyal envanter analizinde; mevcut sistem ve alternatif senaryoların çalışanlar, atık üreticileri, yerel halk ve toplum üzerindeki etkileri incelenmiştir. Sosyal gruplar içerisinde; çalışanlar geri dönüşüm sistemi çalışanlarını, atık üreticileri geri dönüşüm sistemine dahil olan vatandaşları, yerel halk pilot bölgede (Maltepe İlçesi) yaşayan ve sisteme dahil olmayan halk1, toplum geniş ölçekli olarak Türkiye'de yaşayan insanları temsil etmektedir. Bu çalışmanın önceki bölümlerinde, Yıldız-Geyhan ve diğ. [28] tarafindan belirlenen 26 farklı indikatör ile mevcut sistem ve alternatif senaryoların sosyal analizi yapılmıştır (Tablo 2). Bu indikatörlerle temel olarak, çalışanların iş sağlığı ve güvenliği koşulları, gelir düzeyleri, sosyal haklar, iş memnuniyeti, yerel halkın memnuniyeti, toplumda yaratılan iş olanakları ve ekonomiye katkıları incelenmiştir. Envanter verileri toplanırken, atık toplama sisteminde çalışanlarla anket yapılmış, pilot bölgede görsel inceleme yapılarak saha analiz raporları oluşturulmuştur. Mevcut durumda, resmi kurumlar tarafindan yürütülen toplama işinde 50 çalışan varken, sahada kayıt dışı olarak çalışan 800 sokak toplayıcısı bulunduğu belirlenmiştir. Alternatif senaryolar da bu mevcut sistem verilerine göre geliştirilmiştir.

Ekonomik envanter analizinde senaryoların ekonomiye katkısı ölçülmüştür. Bu amaçla net gelir-gider analizi yapılmıştır. Gider analizinde mevcut sistem ve alternatif sistemlerin personel giderleri, araç giderleri, genel yönetim giderleri ve amortisman giderleri incelenerek sabit ve değişken maliyetler hesaplanmıştır. Gelir analizinde ayrıştırılmış atıkların satış değerleri dikkate alınmıştır. Mevcut sistem verileri Maltepe Belediyesi 2016 yilı raporlarından temin edilmiştir [45]. EYDD çalışmalarında kullanılan indikatörler de Tablo 2'de verilmiştir.

Veri güncellemeleri yapıldığında; seçilen pilot bölgedeki atık toplama, çalışan personel (sokak toplayıcısı ve/veya belediye çalışanı), kullanılan araç ve materyal sayısında oransal olarak bir değişim olmadığ 1 görülmüştür. Bu nedenle Yıldız-Geyhan ve diğ. $[20,28]$ tarafindan yapılan çalışmalardaki veriler direkt olarak kullanılmış ve 2016 maliyet analizine entegre edilmiştir. 
Tablo 2. Sürdürülebilirlik analizinde kullanılan veri nitelikleri ve kaynakları

\begin{tabular}{|c|c|c|}
\hline \multicolumn{2}{|c|}{ Veri Niteliği } & Veri Kaynağ1 \\
\hline \multirow{13}{*}{$\begin{array}{l}\text { Çevresel } \\
\text { veriler }\end{array}$} & Toplanan geri dönüştürülebilir atık miktarı & \multirow{13}{*}{ [20] } \\
\hline & Ayrıştırılan geri dönüştürülebilir atık miktarı & \\
\hline & Faydalı yan ürün miktarı & \\
\hline & Artık miktarı & \\
\hline & Kullanılan toplama materyali tipi & \\
\hline & Kullanılan toplama materyali miktarı/ & \\
\hline & Araç tipi ve araç sayısı & \\
\hline & Yakit türü & \\
\hline & Yakıt tüketim miktarı & \\
\hline & Gidilen mesafe & \\
\hline & Elektrik tüketim miktarı & \\
\hline & Su tüketim miktarı & \\
\hline & Isınma için kullanılan yakıt tüketim miktarı & \\
\hline \multirow{26}{*}{$\begin{array}{l}\text { Sosyal } \\
\text { veriler }\end{array}$} & İş kazaları & \multirow{26}{*}[28]{} \\
\hline & İş hastalıklarına yakalanma riski & \\
\hline & Güvenlik ve sağlık farkındalığı & \\
\hline & Sistemin güvenlik riski & \\
\hline & İş sağlığı ve güvenliği eğitimleri & \\
\hline & Uygun iş ekipmanlarıyla çalışma & \\
\hline & Yerel halkın sağlık ve güvenlik koşulları & \\
\hline & Yerel halkın emniyetli yaşam koşulları & \\
\hline & İş memnuniyeti & \\
\hline & Yasal çalışma saatlerine uyumluluk & \\
\hline & Gece çalışması & \\
\hline & Açlık sınırında maaş alan çalışanların varlığ 1 & \\
\hline & Düzenli ödemeler & \\
\hline & Yasal iş sözleşmesi & \\
\hline & Emeklilik hakları & \\
\hline & Sosyal güvenlik hakları & \\
\hline & Eğitim programları & \\
\hline & Zorunlu çalıştırma & \\
\hline & Çocuk iş̧̧i çalıştırma & \\
\hline & Toplu sözleşme ve grev haklarının varlığ & \\
\hline & Siyasi, bölgesel ve dini ayrımcılık & \\
\hline & İş sahası yaratma durumu & \\
\hline & İş kayb1 yaratma durumu & \\
\hline & Sistemi destekleyen kişi sayısı & \\
\hline & Belirlenen şikâyet sayıları & \\
\hline & Sistemin ekonomik gelişime katkısı & \\
\hline \multirow{19}{*}{$\begin{array}{l}\text { Ekonomik } \\
\text { veriler }\end{array}$} & Personel Giderleri & \multirow{18}{*}{ [45] } \\
\hline & Personel toplam kazanç & \\
\hline & SSK giderleri & \\
\hline & Faturalı yemek giderleri & \\
\hline & Personel sağlık giderleri & \\
\hline & Personel kiyafet gideri & \\
\hline & Eğitim ve seminerler & \\
\hline & Araç Giderleri & \\
\hline & Akaryakıt & \\
\hline & Yedek parça & \\
\hline & Araç bakım-onarım giderleri & \\
\hline & Araç vergi-sigorta giderleri & \\
\hline & Araç muayene ve egzoz giderleri & \\
\hline & Ayrıştırma Tesisine Ait Genel Yönetim Giderleri & \\
\hline & Kira giderleri & \\
\hline & Elektrik-su-yakıt giderleri & \\
\hline & Diğer yönetim giderleri & \\
\hline & Amortisman Giderleri & \\
\hline & Satış Gelirleri & \\
\hline
\end{tabular}




\subsection{Etki Değerlendirmesi}

Çevresel etki değerlendirme metodu olarak CML-IA kullanılmıştır. Yorumlama kolaylığı sağlaması açısından bu yöntemle hesaplanan indikatörlerden senaryolar arasında en çok farklılık gösteren altı tanesi seçilmiştir. Bu kapsamda; abiyotik kaynak tükenme potansiyeli (ADP), asidifikasyon potansiyeli (AP), küresel 1sınma potansiyeli (GWP), ozon tabakas1 tükenme potansiyeli (ODP), fotokimyasal oksidasyon oluşturma potansiyeli (POCP), ve ötröfikasyon potansiyeli (EP) incelenmiştir. Veri modellemesi için SimaPro 8.0.1 programı kullanılmıştır ve farklı senaryolar için hesaplanan sonuçlar hem mevcut sistemle hem de birbiriyle kıyaslanmıştır.

Sosyal etki değerlendirme çalışmalarında indikatörler; (UNEP/SETAC, 2009) rehberinde de açıklandığ şekilde skorlama sistemi kullanılarak değerlendirilmiştir. Skorlama sisteminin detayları önceki çalışmamızda açıklanmıştır [28]. Sosyal etki analizi için kullanılan her bir veri, sosyo-ekonomik etkiler dışında, verinin varlığı yokluğu bilgisine göre belirlenmiştir. Örneğin, ölçümlenecek senaryo için "iş kazaları" verisi analiz edilirken: iş kazasının varlığı veya yokluğu incelenmiştir. Eğer verinin referans değeri "hayır" ise, bu iş yerinde herhangi bir kazanın olmadığı anlamına gelmektedir. Hazırlanan 26 veri içinde, sosyo-ekonomik indikatörler (sistemi destekleyen kişi sayısı, şikâyet sayısı, sosyo-ekonomik gelişime katkısı indikatörleri) niceliksel olduğundan dolayı net olarak ölçümlenmiş ve sayısal bir büyüklükle ifade edilmiştir [28].

Ekonomik etki değerlendirme çalışması için belirlenen 21 gider ve 1 gelir verisi direkt olarak ölçülmüştür. Gelir - gider analizinden sonra net kazanç verisi hesaplanarak, her bir senaryo için toplam ekonomik etki verisi oluşturulmuştur.

Her bir senaryo için; çevresel, sosyal ve ekonomik etkilerin envanter dataları toplandiktan sonra (Ek 1-3), bütün etkileri temsilci bir skorla ifade etmek üzere sürdürülebilir yaşam döngüsü analizi gerçekleştirilmiştir. Etkilerin tek skorda dağılımının ifade edilmesinde en önemli husus normalizasyon ve ağırlıklandırmadır. Birimsiz bir büyüklüğe indirgenen her bir verinin, kendi etki analizi grubu içerisinde (çevresel, sosyal ve ekonomik) eşit ağırlıkta bir etkiye sahip olduğu düşünülmüştür. Böylelikle, eşit ağırlıklandırma metodu kullanılarak her bir etki grubu için temsilci bir sonuç skoru elde edilmiştir.

Çevresel, sosyal ve ekonomik etki değerlendirme skorlarını sürdürülebilirlik skoru adı altında temsilci bir sonuç skoruyla ifade etmek için etki grupları üzerinden son bir ağırlıklandırma daha yapılmıştır. Sürdürülebilirlik skorunun elde edilmesinde, çevresel, sosyal ve ekonomik etkiler farklı ağırlıklarda olabilmektedir. $\mathrm{Bu}$ durum farklı senaryoların değerlendirilmesi ihtiyacını ortaya koyar. $\mathrm{Bu}$ çalışmada; bütün sürdürülebilirlik boyutlarının eşit ağırlıkta bir etkiye sahip olduğu, çevresel boyut etkisinin ağırlıkta olduğu, sosyal boyut etkisinin ağırlıkta olduğu ve ekonomik boyut etkisinin ağırlıkta olduğu 7 farklı ağırlıklandırma kombinasyonu oluşturulmuştur. $\mathrm{Bu}$ farklı ağırlıklandırma seçenekleriyle farklı perspektifleri yansıtan sürdürülebilirlik skorları hesaplanmış ve kıyaslanmıştır. Normalizasyon ve ağırlıklandırma yöntemleri bir sonraki bölümlerde detaylı bir şekilde açıklanmıştır.

\subsubsection{Normalizasyon}

Karşılaştırılabilir tekil bir skor elde etmek ve çevreselsosyal-ekonomik etki skorlarını toplayabilmek için, etki skorlarının normalize edilmesi gerekmektedir. Normalizasyon, farklı büyüklüklerdeki ve birimlerdeki indikatörlerin genel bir skalaya indirgenmesi için yapılan bir hesaplamadır. Bu sayede farklı birimlerdeki skorlar kolaylıkla karşılaştırılabilir [46,47].

Bu çalışmadaki SYDD sonuçları, "min-max lineer normalizasyon metodu" kullanılarak elde edilmiştir. Bu metot, sonuçları $0-1$ aralığında standardize etmektedir. " 0 " en kötü sonucu ifade ederken, " 1 " en iyi sonucu ifade etmektedir. S-YDD ve E-YDD skorlama sisteminde sonuçlar pozitif bir faydayı ifade ettiğinden direkt korelasyon denklemi kullanılmıştır (Eşitlik 1). Diğer taraftan, Ç-YDD skorlarında değerin büyüklüğü negatif bir durumu ifade ettiğinden, tersinir korelasyon metodu kullanılmıştır (Eşitlik 2) [48].

Direkt korelasyon için:

$u\left(x_{k}\right)=\frac{\left(x_{k}-x_{\min }\right)}{\left(x_{\max }-x_{\min }\right)}$

Tersinir korelasyon için:

$u\left(x_{k}\right)=\frac{\left(x_{\max }-x_{k}\right)}{\left(x_{\max }-x_{\min }\right)}$

Burada;

$\mathrm{x}_{\mathrm{k}} \quad$ : $\mathrm{k}$ senaryosu için indikatör değeri,

$\mathrm{x}_{\min } \quad$ : indikatörün minimum değeri,

$\mathrm{x}_{\max }$ : indikatörün maksimum değerini ifade etmektedir.

\subsubsection{A ğırlıklandırma}

Ağırlıklandırma, karşılaştırma yapmak amacıyla, farklı indikatörlerden oluşan her bir SYDD bileşeninin etkilerinin tek bir nümerik büyüklükle ifade edilebilmesi için yapılan bir hesaplamadır. Bu çalışmada 2 basamaklı bir ağırlıklandırma sistemi kullanılmıştır. İlk olarak, her bir SYDD bileşenine ait indikatörler kendi aralarında ağırlıklandırılmış ve bileşene ait tek bir nümerik büyüklük elde edilmiştir. Ardından, etkileri tek bir skorla ifade edilen bileşenler kendi aralarında tekrar ağırlıklandırılmış ve SYDD'ne ait tekil bir skor elde edilmiştir. Böylelikle toplam sürdürülebilirlik skoru elde edilen mevcut sistem ve alternatif senaryolar birbiriyle kıyaslanabilir şekle getirilmiştir. 
Ağırlıklandırma yöntemi olarak; S-YDD ve E-YDD indikatörleri için "Eşit Ağırlıklar Yöntemi" kullanılırken, Ç-YDD için SimaPro 8.0.1 programından RECIPE tek skor sonuçları direkt olarak alınmıştır. Bileşenlerden toplam bir SYDD skoru elde etmek için de "Eşit Ağırlıklar Yöntemi" ve "DereceSıralama Ağırlık Yöntemi” kullanılmıştır.

Eşit ağırlıklar ve derece sıralama ağırlıklar yöntemlerine ait hesaplama metodu aşağıda verilmiştir. Eşit ağırlıklar yöntemine göre Eşitlik 3 kullanıldığında 3 bileşeninde toplam SYDD skorunu 0,33 ağırlığında etkilene tek bir ağırlıklandırma kombinasyonu (K1) oluşturulmuştur. Derece-sıralama ağırlık yöntemine göre ise nitelikler 1., 2., 3. şeklinde 3 önem sırasına göre sıralanmış, Eşitlik 4'ten niteliklerin ağırlık oranları belirlenmiş ve bu 6 farklı kombinasyon (K2, K3, K4, K5, K6, K7) oluşturulmuştur. Nitelik sayıları az olduğundan, bütün ağırlıklandırma kombinasyonları hesaplanmış ve Tablo 4'te gösterilmiştir.

Normalizasyon ve ağırlıklandırma adımlarının tamamlanmasıyla; ekonomik, çevresel ve sosyal bileşenleri içeren tekil bir toplam skor elde edilmiştir.

Eşit Ağırlıklar Yöntemi:

$\mathrm{w}_{1}=\mathrm{w}_{2}=\ldots .=\mathrm{w}_{\mathrm{n}} \geq 0$ ve $\sum \mathrm{w}_{\mathrm{j}}=1$ olmak üzere,

$\mathrm{w}_{\mathrm{j}}=1 / \mathrm{n} \quad \mathrm{j}=1,2 \ldots ., \mathrm{n}$

Derece-Sıralama Ağırlık Yöntemi:

$\mathrm{w}_{1} \geq \mathrm{w}_{2} \geq \ldots . \geq \mathrm{w}_{\mathrm{n}} \geq 0$ ve $\sum \mathrm{w}_{\mathrm{j}}=1$ olmak üzere,

$\mathrm{W}_{\mathrm{i}}=\frac{1}{n} \cdot \sum_{j=1}^{n} 1 / j$

Burada;

$\mathrm{W}_{\mathrm{i}} \quad$ : niteliklerin ağırlık oranı

n : nitelik sayıs1

i : niteliklerin önem sırasını ifade etmektedir.

\subsection{Yorumlama}

Yorumlama, YDD çalışmalarının son basamağı olarak hem envanter analizi hem de etki değerlendirme aşamalarında elde edilen sonuçların kapsamlı bir şekilde değerlendirilmesini içerir. SYDD çalışmasına ait yorumlama Bölüm 3'te detaylı bir şekilde yapılmıştır.

\section{BULGULAR VE TARTIŞMA}

Mevcut sistem ve bu sisteme alternatif olarak geliştirilen senaryolara ait her bir sürdürülebilirlik bileşeninin normalizasyon yapılmadan tekil analizleri Tablo 3'te verilirken, verilerin normalizasyonundan sonraki tekil analizleri Şekil 1'de verilmiştir.

Tablo 3 ve Şekil 1'de Çevresel etkiler incelendiğinde; 2'li ayrıştırmanın uygulandığı, karışık ambalaj atıklarının kısmi entegreli sistemle, camların yetkilendirilmiş kurumlar tarafindan toplandığ senaryonun (S5) en etkili sistem olduğu görülürken, atıkların sadece yetkilendirilmiş kurumlar tarafindan toplanmasının öngörüldüğü 3 numaralı senaryonun (S3) ise en dezavantajlı sistem olduğu görülmüştür. Yine çevresel açıdan değerlendirme sonuçlarına bakıldığında; sokak toplayıcılarının sistemde olduğu mevcut sistem (MS) ve entegre sistemlerin (S6), sırasıyla 2. ve 3.sırada yer aldığı gözlemlenmiştir. Sokak toplayıcıların dâhil olduğu diğer bir senaryo olan S4'ün ise çevresel açıdan etkili bir sistem olmadığı belirlenmiştir. Bunun sebebinin; cam atıkların sokak toplayıcılar tarafindan toplanmayıp sadece yetkili kurumlar tarafından toplanması olduğu, Yıldız-Geyhan ve diğ. [20] tarafindan yapılan çalışmalara dayanarak söylenebilir.

Senaryolara ait sosyal etkiler incelendiğinde ise; sosyal şartlarda iyileştirme yapılarak sokak toplayıcılarının tamamının ve bir kismının sisteme entegrasyonun sağlandığ $\mathrm{S} 6$ ve S5'in sirasiyla 1. ve 2. sirada yer aldığ 1 görülmüştür. Diğer taraftan sokak toplayıcılarına herhangi bir sosyal iyileştirmenin yapılmayıp, mevcut şartlarıyla çalıştığının öngörüldüğü senaryoların (MS ve S4) ise sosyal olarak dezavantajlı olduğu görülmüştür.

Ekonomik etkilere bakıldığında; sokak toplayıcıların mevcut koşullarıyla sistemde var olduğunun öngörüldüğü senaryoların ekonomik olarak daha etkili olduğu görülmüştür. Yıldız-Geyhan ve diğ. [28]'nin çalışmalarında da belirttikleri gibi; sokak toplayıcıları herhangi bir ayrıştırma, toplama, taşıma materyali gerektirmeden toplama-taşıma faaliyeti gerçekleştirmesinden ve herhangi bir kuruma bağlı olmaksızın çalışmalarından dolayı, yetkilendirilmiş kurumlarla kıyaslandığında çok ekonomik gidere sahip değillerdir (Tablo 3). Bu sebeple; ambalaj atığ1 toplama-taşıma sistemlerindeki ekonomik girdileri ekonomik çıktılarından çok daha fazladır. Diğer taraftan; sokak toplayıcılarının sisteme entegrasyonun yapıldığı S5 ve S6'nın ise ekonomik olarak dezavantajlıdır (Şekil 1).

Sürdürülebilirlik bileşenleri genel olarak irdelenirse; çevresel ve ekonomik bileşenlerin etkisinde, toplanan atık miktarının fazlalığı önemli iken; sosyal bileşenin etkisinde çalışanların sosyal şartlarının iyileştirilip iyileştirilmediğinin önemli olduğu görülmektedir.

Sürdürülebilirlik bileşenlerinin Şekil 1'de gösterilen tekil etki analizlerinin Bölüm 2.3.2'de belirtilen yöntemle ağırlıklandırılması neticesinde Şekil 2'de 7 farklı senaryonun karşılaştırmalı sürdürülebilirlik analizi sonuçları elde edilmiştir.

Çevresel, sosyal ve ekonomik etkilerin farklı ağırlıklandırmalarının sonuçlarını objektif bir şekilde karar vericilere göstermek için hesaplanan 7 farklı ağırlıklandırma kombinasyonu ile 7 farklı toplam sürdürülebilirlik skoru elde edilmiştir. 
Tablo 3. SYDD bileşenlerinin etki değerlendirme sonuçları

\begin{tabular}{|l|l|l|l|}
\hline & Toplam Çevresel Etki & Toplam Sosyal Etki & Toplam Ekonomik Etki \\
\hline MS & $-2,612 \mathrm{E}+00$ & $2,708 \mathrm{E}-01$ & $3,870 \mathrm{E}+06$ \\
\hline S1 & $-4,335 \mathrm{E}-01$ & $6,806 \mathrm{E}-01$ & $-1,983 \mathrm{E}+06$ \\
\hline S2 & $-3,993 \mathrm{E}-01$ & $7,500 \mathrm{E}-01$ & $-2,399 \mathrm{E}+06$ \\
\hline S3 & $-1,099 \mathrm{E}-01$ & $6,875 \mathrm{E}-01$ & $-7,138 \mathrm{E}+05$ \\
\hline S4 & $-2,455 \mathrm{E}+00$ & $2,708 \mathrm{E}-01$ & $1,579 \mathrm{E}+07$ \\
\hline S5 & $-2,706 \mathrm{E}+00$ & $8,194 \mathrm{E}-01$ & $-4,624 \mathrm{E}+06$ \\
\hline S6 & $-2,565 \mathrm{E}+00$ & $1,000 \mathrm{E}+00$ & $-7,983 \mathrm{E}+06$ \\
\hline
\end{tabular}

Tablo 4. SYDD tekil toplam skoru için ağırlıklandırma katsayısı kombinasyonları

\begin{tabular}{|l|l|l|l|l|l|l|l|}
\hline & K1 & K2 & K3 & K4 & K5 & K6 & K7 \\
\hline Çevresel Etki & 0,33 & 0,611 & 0,611 & 0,112 & 0,277 & 0,112 & 0,277 \\
\hline Sosyal Etki & 0,33 & 0,277 & 0,112 & 0,611 & 0,611 & 0,277 & 0,112 \\
\hline $\begin{array}{l}\text { Ekonomik } \\
\text { Etki }\end{array}$ & 0,33 & 0,112 & 0,277 & 0,277 & 0,112 & 0,611 & 0,611 \\
\hline
\end{tabular}

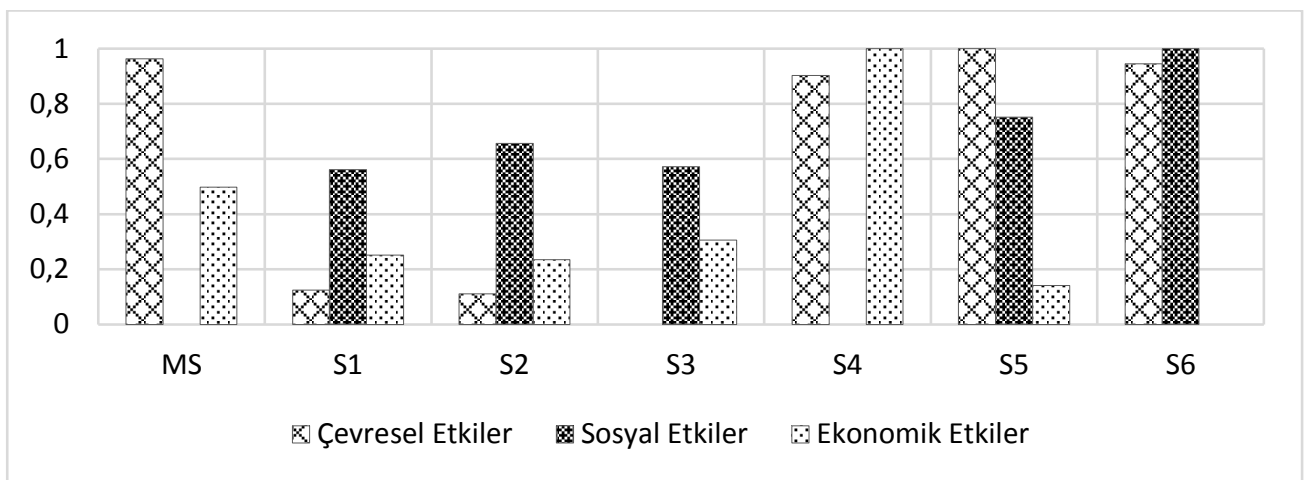

Şekil 1. Ambalaj atığı toplama senaryolarının sürdürülebilirlik bileşenlerinin analizi

Şekil 2.a'da 3 sürdürülebilirlik bileșeninin ağırlıklarının birbirine eşit olduğu bir sürdürülebilirlik senaryosu (K1) sonuçları görülmektedir. Çevresel, ekonomik ve sosyal etkilerin önem sıralamasının eşit olduğu varsayıldığında; atık toplama miktarlarının fazla olduğu sokak toplayıcı temelli senaryoların avantajlı senaryolar olduğu, bunların arasında da bütün çalışanların sisteme entegrasyonu ile sosyal iyileştirmenin yapıldığ 1 S6'nın en iyi senaryo olduğu görülmüştür. Diğer taraftan, sokak toplayıcılarının elimine edilip toplamanın sadece yetkili kurumlar tarafından yapıldığ1 senaryoların ise (S1, S2 ve S3) düşük sürdürülebilirlik skoruna sahip olduğu görülmüştür.

Şekil 2.b'den çevresel etkinin 1., sosyal etkinin 2., ekonomik etkinin 3. sırada öneme sahip olduğu sürdürülebilirlik senaryosunun (K2) sonuçları incelendiğinde; eşit ağırlıklandırma ile benzer bir şekilde S6 ve S5'in en iyi senaryolar olduğu, diğer taraftan S4 ün ise en kötü senaryo olduğu görülmüştür. Daha önceden de belirtildiği gibi, S4 senaryosunda cam atıklarının toplanmaması çevresel açıdan olumsuz bir etki yaratmakta ve önemin çevresel ağırlıkta değerlendirildiği durumlarda da tercih siralamasını değiştirmektedir.

Şekil 2.c'de çevresel etkinin 1., ekonomik etkinin 2., sosyal etkinin 3. sırada öneme sahip olduğu sürdürülebilirlik senaryosunun (K3) sonuçları görülmektedir. $\mathrm{Bu}$ senaryoda çevresel etkinin önem sıralaması sabit tutulup sosyal ve ekonomik etkinin sıralaması değiştirilmiştir. K2 ile kıyaslandığında toplama senaryoları arasında ciddi bir değişiklik gözlenmemekle birlikte, kısmi entegrasyonun yapıldığı S5 toplama senaryosu en iyi senaryo olduğu, S4'ün ise hala en dezavantajlı senaryo olduğu görülmüştür. Tam entegrasyonun uygulandığı S6'nın S5'e göre daha maliyetli bir sistem olması bu önem sıralaması değişikliğinin bir nedeni olarak açıklanabilir.

Şekil 2.d'de sosyal etkinin 1., ekonomik etkinin 2., çevresel etkinin 3. sırada öneme sahip olduğu sürdürülebilirlik senaryosunun (K4) sonuçları görülmektedir. K4 sürdürülebilirlik senaryosunda; tam entegre sistem senaryosu olan S6 en avantajlı senaryo iken, mevcut sistemin en dezavantajlı senaryodur. Bölüm 2'de senaryo açıklamalarında da belirtildiği gibi 3veriler ve Şekil 1 birlikte değerlendirildiğinde, S6 toplanan atık miktarının ve sosyal iyileştirme oranın en fazla olduğu senaryodur. Bu nedenle çevresel ve sosyal faydalar açısından dikkate değer sonuçlar göstermektedir. Diğer taraftan, mevcut sistemde herhangi bir sosyal iyileştirme söz konusu olmadığından en dezavantajlı senaryo olmuştur. Diğer sürdürülebilirlik senaryolarından farklı bir şekilde, bu senaryoda yetkilendirilmiş kurum tarafindan 2'li ayrıştırma şeklinde kumbaralarla yapılan toplama senaryosunun (S3) 2. en avantajlı senaryo olduğu 
görülmektedir. Bunun sebebinin toplama sisteminde çalışanlarının tamamının sosyal şartlarının minimum düzeyde iyileştirilmiş olduğu öngörüsüyle senaryonun kurgulanmasındandır.

Şekil 2.e'de sosyal etkinin 1., çevresel etkinin 2., ekonomik etkinin 3. sırada öneme sahip olduğu sürdürülebilirlik senaryosunun (K5) sonuçları görülmektedir. $\mathrm{Bu}$ sürdürülebilirlik senaryosunda $\mathrm{K} 4$ senaryosundan farklı olarak çevresel etki ile ekonomik etkinin önem sırası değiştirilmiş ve çevresel etkinin ekonomik etkiye göre daha önemli olduğu kabulü yapılmıştır. Sosyal bileşen ise hala en önemli etkiye sahiptir. $\mathrm{Bu}$ kabulle şekil incelendiğinde, K5 sürdürülebilirlik senaryosundaki sıralamaların K4 senaryosu ile hemen hemen aynı sonuçları gösterdiği, sadece $S 2$ ve $S 4$ toplama senaryolarının siralamasının değiştiği görülmüştür. Bunun sebebinin de S2'nin çevresel olarak S4'ten daha fazla bir faydaya sahip olduğu söylenebilir.

Son olarak, ekonomik etkinin öncelikli olduğu varsayımıyla oluşturulan sürdürülebilirlik senaryoları K6 ve K7 incelendiğinde; bu senaryoların diğer sürdürülebilirlik senaryolarından farklı sıralama sonuçlarının elde edildiği görülmüştür (Şekil 2.f ve 2.g). Ekonomik etkinin öncelikli olduğu durumlarda, S4 sıralamada belirgin bir şekilde yüksek bir skora sahipken, bunu sırasıyla MS, S5 ve S6 izlemiştir. Diğer sürdürülebilirlik senaryolarında yüksek skorlara sahip olan S5 ve S6'nın ekonomik analiz dikkate alındığında aynı performansı gösteremediği görülmüştür. Bunun sebebi, tam entegrasyonda ve kismi entegrasyonda öngörülen sosyal iyileştirmenin ekonomik maliyetinin yüksek olmasıdır.

Hesaplamalar sonunda ulaşılan sonuçlarda, farklı ağırlıklandırma tercihlerinin birbirinden farklı sürdürülebilirlik skorları oluşturması, bu türdeki çalışmaların öznelliğini ortaya koymaktadır (Tablo 5). Karar verici mekanizmaların kendi önceliklerine göre oluşturacağı farklı ağırlıklandırma tercihleri sonucu, uygulamak isteyecekleri senaryolar farklılık gösterecektir. Bu çalışmanın amacı, teorik olarak mümkün olan tüm farklı tercihleri göz önüne alarak bir sürdürülebilirlik sıralaması yapmak ve objektif bir şekilde sunmaktır. Genel bir değerlendirme yapıldığında 7 farklı kombinasyon içinden dördünde en iyi sonucu veren senaryonun, bu çalışmada önerilen entegre sistem olduğu (S6) sonucuna varılabilir.

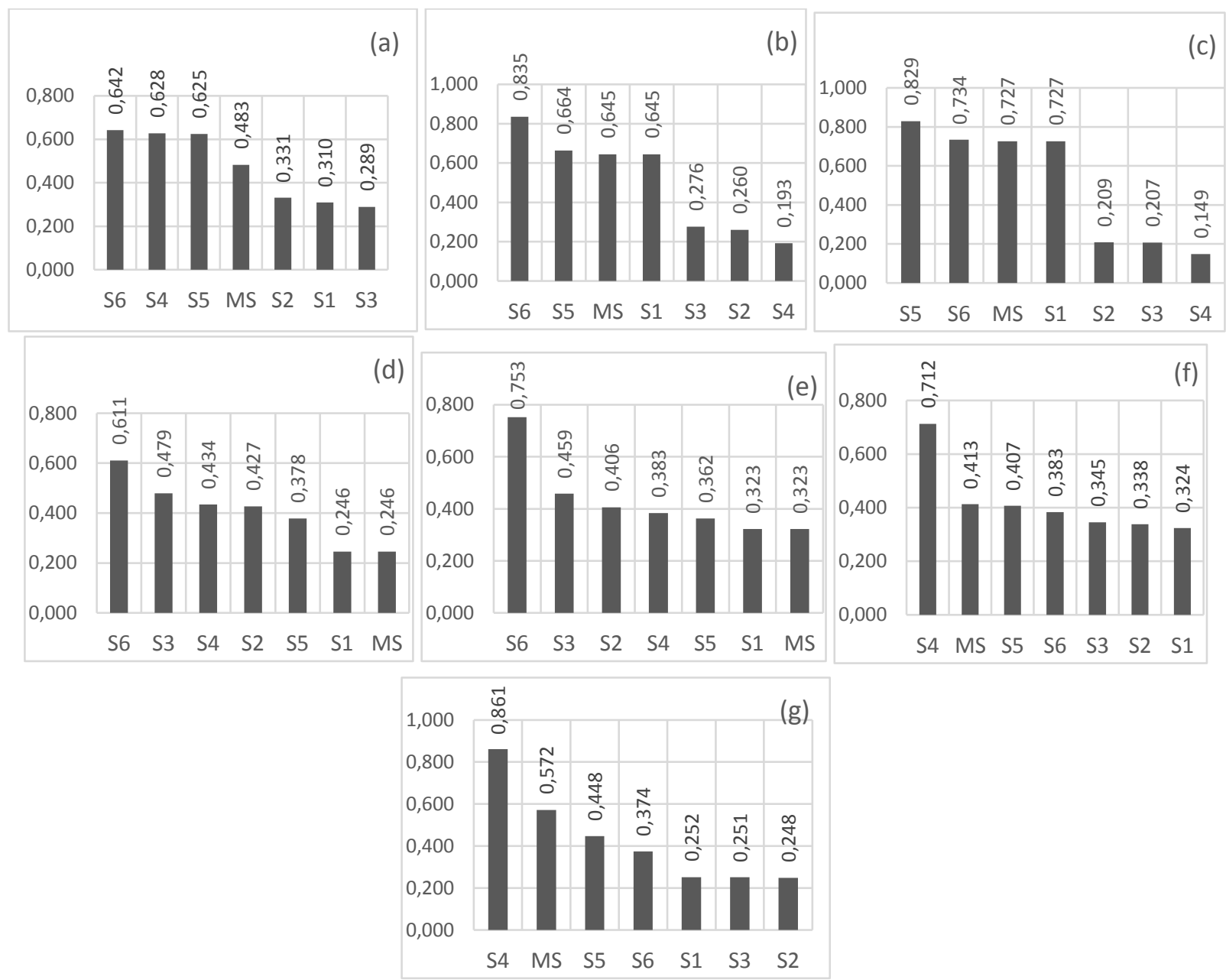

Şekil 2. Ambalaj atığı toplama senaryolarının karşılaştırmalı sürdürülebilirlik analizi: (a) Sürdürülebilirlik kombinasyonu 1 (K1), (b) K2, (c) K3, (d) K4, (e) K5, (f) K6, (g) K7 
Tablo 5. Farklı ağırlıklandırma tercihlerine göre en iyi ve en kötü senaryo alternatifleri

\begin{tabular}{|l|l|l|l|l|l|l|l|}
\hline & K1 & K2 & K3 & K4 & K5 & K6 & K7 \\
\hline En iyi & S6 & S6 & S5 & S6 & S6 & S4 & S4 \\
\hline En kötü & S3 & S4 & S4 & MS & MS & S1 & S2 \\
\hline
\end{tabular}

IV. SONUÇ VE GELECEK ÇALIŞMALAR

Bu çalışma ile Türkiye'de ilk kez ambalaj atıklarının toplanmasında çevresel, sosyal ve ekonomik yaşam döngüsü değerlendirme çalışması yapılmış ve sürdürülebilir bir ambalaj atığı toplama sistemi önerilmiştir.

Çalışmanın temel bulguları özetle aşağıdaki şekilde siralanabilir:

- Çevresel yaşam döngüsü değerlendirmesi sonucunda; 2'li ayrıştırmanın uygulandığı, karışık ambalaj atıklarının kısmi entegreli sistemle, camların yetkilendirilmiş kurumlar tarafından toplandığ1 senaryonun (S5) en etkili sistem olduğu görülmüştür.

- Sosyal yaşam döngüsü değerlendirmesi sonucunda; sosyal şartlarda iyileştirme yapılarak sokak toplayıcılarının tamamının ve bir kısmının sisteme entegrasyonun sağlandığı senaryonun (S6) en iyi seçenek olduğu görülmüştür.

- Ekonomik yaşam döngüsü değerlendirmesi sonucunda; sokak toplayıciların mevcut koşullarıyla sistemde var olduğunun öngörüldüğü senaryonun (S4) daha iyi olduğu görülmüşsür.

- Sürdürülebilirlik bileşenleri genel olarak irdelenirse; çevresel ve ekonomik bileşenlerin etkisinde, toplanan atık miktarının fazlalığı önemli iken; sosyal bileşenin etkisinde çalışanların sosyal şartlarının iyileştirilip iyileştirilmediğinin önemli olduğu görülmektedir.

- Gerçekleştirilen YDD çalışmaları sonunda her bir senaryonun temsilcisi olacak şekilde sürdürülebilirlik skorları hesaplanmıştır. $\mathrm{Bu}$ sürdürülebilirlik skorları hesaplanırken çevresel, sosyal ve ekonomik etkilerin farklı ağırlıklandırılmalarını içeren 7 alternatif hesaplama yapılmıştır.

- Hesaplanan sürdürülebilirlik skorları, karar verici mekanizmaların kendi önceliklerine göre oluşturacağı farklı ağırlıklandırma tercihlerinin birbirinden farklı sonuç skorları yaratacağını göstermiştir.

- Bu çalışmada, teorik olarak mümkün olan tüm farklı tercihler objektif bir şekilde göz önüne alınarak bir sürdürülebilirlik sıralaması yapılmıştır.

- Genel bir değerlendirme yapıldığında 7 farklı kombinasyon içinden dördünde en iyi sonucu veren senaryonun, bu çalışmada önerilen entegre sistem olduğu (S6) sonucuna varılabilir.

Bu sonuçlar dikkate alınarak ilerleyen çalışmalar için aşağıdaki öneriler yapılabilir:
- $\mathrm{Bu}$ çalışmayla geliştirilen yöntem geniş kullanım alanı bulduğunda yıllık olarak istatistiksel verilerle güncel hesaplamaların yapılması imkânı da doğacaktır.

- Farklı etkileri gözlemleyebilmek için ÇYDD, EYDD ve SYDD için kullanılan indikatörler çeşitlendirilebilir.

- Envanter analizi çalışmaları perspektifi genişletilebilir.

- Evsel katı atık yönetim sisteminin tamamı sistem sinırlarına dâhil edilebilir.

- Ulaşımda alternatif araçların ve/veya yakıtların kullanımı değerlendirilerek, ulaşımın çevresel etkisinin minimize edilmesi için farklı senaryolar geliştirilebilir.

- Sıfır atık uygulamalarının etkisinin irdelenip dâhil edildiği senaryolar geliştirilebilir.

- Ambalaj atıklarının geri dönüşümü geniş kapsamlı olarak sistem sınırlarına dâhil edilebilir.

- Geri dönüşüm sistemlerinde alternatif teknolojiler araştırılarak farklı senaryolar oluşturulabilir.

\section{TEŞEKKÜR}

Yazarlar Maltepe Belediyesi Çevre Koruma ve Kontrol Müdürlüğü'ne, FEN-C-DRP-150513-0186, FEN-CDRP-150513-0175 ve FEN-C-YLP-120418-0169 numaralı projelere desteklerinden ötürü Marmara Üniversitesi Bilimsel Araştırma Proje Koordinasyon Birimi (BAPKO)'ya teşekkür etmektedir.

\section{KAYNAKLAR}

[1] Katı atıkların kontrolü yönetmeliği, 20814 sayılı resmi gazete, Mart 14, 1991.

[2] Ambalaj atıklarının kontrolü yönetmeliği, 25538 sayılı resmi gazete, Temmuz 30, 2004.

[3] Ambalaj atıklarının kontrolü yönetmeliği, 26562 say1lı resmi gazete, Haziran 24, 2007.

[4] Ambalaj atıklarının kontrolü yönetmeliği, 28035 sayılı resmi gazete, Ağustos 24, 2011.

[5] Ambalaj atıklarının kontrolü yönetmeliği, 3028327 sayılı resmi gazete, Aralık 27, 2017.

[6] Atık getirme merkezi tebliği, 29222 sayılı resmi gazete, Aralık 31, 2014.

[7] Sıfır atık yönetmeliği, 30829 sayılı resmi gazete, Temmuz 12, 2019.

[8] Y1ld1z-Geyhan, E. (2016). Environmental analysis of different packaging waste collection systems for Istanbul - Turkey case study. Doktora Tezi, Marmara Üniversitesi, Türkiye.

[9] Laurent, A., Bakas, I., Clavreul, J., Bernstad, A., Niero, M., Gentil, E., Hauschild, M.Z., ve Christensen, T.H. (2014). Review of LCA studies of solid waste management systems - Part I: Lessons learned and perspectives. Waste Manage 34,573-588. 
[10] Manfredi, S., Tonini, D., ve Christensen, T.H. (2011). Environmental assessment of different management options for individual waste fractions by means of lifecycle assessment modelling. Resources, Conser. Recyc., 55, 995-1004.

[11] Larsen, A.W., Merrild, H., Moller, J., ve Christensen, T.H. (2010). Waste collection systems for recyclables: An environmental and economic assessment for the municipality of Aarhus (Denmark). Waste Manage, 30, 744-754.

[12] Hunt, R.G. (1995). LCA considerations of solid waste management alternatives for paper and plastics. Resources, Conser. Recyc., 14, 225-231.

[13] Merrild, H., Larsen, A.W., ve Christensen, T.H. (2012). Assessing recycling versus incineration of key materials in municipal waste: the importance of efficient energy recovery and transport distances. Waste Manage, 32, 1009-1018.

[14] Rigamonti, L., Grosso, M., ve Guigliano, M. (2009). Life cycle assessment for optimizing the level of separated collection in integrated MSW management systems. Waste Manage, 29, 934-944.

[15] Rigamonti, L., Grosso, M., ve Guigliano, M. (2010). Life cycle assessment of sub-units composing a MSW management system. J. Clean. Prod., 18, 16521662.

[16] Banar, M., Cokaygil, Z., ve Ozkan, A. (2009). Life cycle assessment of solid waste management options for Eskisehir, Turkey. Waste Manage. 29, 54-62.

[17] Özeler, D., Yetis, Ü., ve Demirer, G.N. (2006). Life cycle assessment of municipal solid waste management methods: Ankara case study. Environment International, 32, 405-411.

[18] Erses Yay, A.S. (2015). Application of Life Cycle Assessment (LCA) for Municipal Solid Waste Management: A Case Study of Sakarya. J. Clean. Prod., 94, 284-293.

[19] Erses Yay, A.S. (2018). Yaşam döngüsü analizinin ambalaj atıklarının yönetiminde kullanılması, Sakarya Üniversitesi Fen Bilimleri Enstitüsü Dergisi, 21 (5), 1008-1017.

[20] Yildiz-Geyhan, E., Y1lan-Ciftci, G., AltunCiftcioglu, G.A., ve Kadirgan, M.A.N. (2016) Environmental analysis of different packaging waste collection systems for Istanbul - Turkey case study. Resources, Conser. Recyc., 107, 27-37.

[21] Teerioja, N., Moliis, K., Kuvaja, E., Ollikainen, M., Punkkinen, H., ve Merta, E. (2012). Pneumatic vs. door-to-door waste collection systems in existing urban areas: a comparison of economic performance. Waste Manage, 32, 1782-1791.

[22] Vinyes E., Oliver-Sola J., ve Ugaya C. (2013). Application of LCSA to used cooking oil waste management. Int. J. Life Cycle Ass., 18, 445-455.

[23] Umair S., Björklund A., ve Ekener-Petersen E. (2013). Social Life Cycle Inventory and Impact Assessment of Informal recycling of Electronic ICT. The First International Conference on Information and Communication Technologies for Sustainability, ETH Zurich, February 14-16.
[24] Ferrao, P., Ribeiro, P., Rodrigues, J., Marques, A., Preto, M., Amaral, M., Domingos, T., Lopes, A., ve Costa, I. (2013). Environmental, economic and social cost and benefits of a packaging waste management system: A Portuguese case study. Resources, Conser. Recyc., 85, 67-78.

[25] Foolmaun, R. ve Ramjeeawon, T. (2013). Comparative life cycle assessment and social life cycle assessment of used polyethylene terephthalate (PET) bottles in Mauritius. Int. J. Life Cycle Ass., 18, 155171.

[26] Aparcana, S. ve Salhofer, S. (2013). Development of a social impact assessment methodology for recycling systems in low-income countries. Int. J. Life Cycle Ass., 18, 1106-1115.

[27] Aparcana, S. ve Salhofer, S. (2013). Application of a methodology for the social life cycle assessment of recycling systems in low income countries: three Peruvian case studies. Int. J. Life Cycle Ass., 18, 11161128.

[28] Yıldı-Geyhan, E., Altun-Ciftcioglu, ve G.A., Kadirgan, M.A.N. (2017). Social analysis of different packaging waste collection system. Resources, Conser. Recyc., 124, 1-12.

[29] Miller, B., Spertus, J., Kamga, C., 2014. Costs and benefits of pneumatic collection in three specific New York City cases. Waste Manage. 34, 1957-1966.

[30] Greco, G., Allegrini, M., Del Lungo, C., Savellini, P.G., Gabellini, L., 2015. Drivers of solid waste collection costs. Empirical evidence from Italy. J. Clean. Prod. 106, 364-371.

[31] D’Onza, G., Greco, G., Allegrini, M., 2016. Full cost accounting in the analysis of separated waste collection efficiency: a methodological proposal. J. Environ. Manage. 167, 59-65.

[32] Pires A, Sargedas J, Miguel M, Pina J, Martinho G., 2017. A case study of packaging waste collection systems in Portugal - Part II: Environmental and economic analysis. Waste Manag. 61, 108-116.

[33] Mora, C., Manzini, R., Gamberi, M., Cascini, A., 2014. Environmental and economic assessment for the optimal configuration of a sustainable solid waste collection system: a 'kerbside' case study. Prod. Plan. Control 25, 737-761.

[34] Ana Pires, João Sargedas, Mécia Miguel, Joaquim Pina, Graça Martinho, 2016. A case study of packaging waste collection systems in Portugal - Part II: Environmental and economic analysis. Waste Manage. 61, 108-116.

[35] González-Boubeta, I., Fernández-VázquezNoguerol, M., Domínguez-Caamaño, P., Prado-Prado, J.C., 2018. Economic and Environmental Packaging Sustainability: A Case Study, Journal of Industrial Engineering and Management.11(2), 229-238

[36] Klöpffer, W. (2008). Life cycle sustainability assessment of products. Int. J. Life Cycle Ass., 13, 8995.

[37] Finkbeiner, .M., Schau, E.M., Lehmann, A., ve Traverso, M. (2010). Towards Life Cycle 
Sustainability Assessment, Sustainability, 2, 33093322.

[38] Traverso, M., Asdrubali, F., Francia, A. ve Finkbeiner, M. (2012). Towards life cycle sustainability assessment: an implementation to photovoltaic modules. Int. J. Life Cycle Ass., 17, 1068 1079.

[39] Lu, B., Li, B., Wang, L., Yang, J., Liu, J., ve Wang, V. (2014). Reusability based on Life Cycle Sustainability Assessment: Case Study on WEEE, Procedia CIRP, 15, 473-478.

[40] Martínez-Blanco, J., Lehmann, A., Muñoz, P., Antón, A., ve Traverso, M., Rieradevall, J., Finkbeiner, M. (2014). Application challenges for the social Life Cycle Assessment of fertilizers within life cycle sustainability assessment, J. Clean. Prod., 69, 34-48.

[41] Atılgan, B. ve Azapagic, A. (2016). Assessing the Environmental Sustainability of Electricity Generation in Turkey on a Life Cycle Basis, Energies, 9 (1), 31.

[42] Hosseinijou, S.A., Mansour, S., ve Shirazi, M.A. (2014). Social life cycle assessment for material selection: a case study of building materials. Int. J. Life Cycle Ass., 19, 620-645.
[43] ISO 14040 international standard. In: Environmental Management -Life Cycle Assessment Principles and Framework. International Organisation for Standardization, Geneva, Switzerland, 2006.

[44] ISO 14044 international standard. In: Environmental Management - Life Cycle Assessment Requirements and Guidelines. International Organisation for Standardisation, Geneva, Switzerland, 2006.

[45] Maltepe Belediyesi Faaliyet Raporu-2016. (2017) İstanbul, Türkiye.

[46] Guinee, J, B., Huppes, G., ve Heijungs, R. (2001). Developing an LCA guide for decision support. Environ. Manage Health, 12 (3), 301 - 311.

[47] Ibáñez-Forés, V., Bovea, M.D., ve Pérez-Belis, V. (2014). A holistic review of applied methodologies for assessing and selecting the optimal technological alternative from a sustainability perspective. J. Clean. Prod., 70, 259-281.

[48] Maxim, A. (2014). Sustainability assessment of electricity generation technologies using weighted multi-criteria decision analysis. Energ. Policy, 65, 284297. 


\section{EKLER}

\begin{tabular}{|c|c|c|c|c|c|c|c|}
\hline Gider Kalemleri (TL) & MS & S1 & $\mathbf{S 2}$ & S3 & S4 & S5 & S6 \\
\hline \multicolumn{8}{|l|}{ Resmi Sistem Gider Kalemleri } \\
\hline Personel toplam kazanç & 911910 & 911910 & 1103410 & 328287 & 0 & 3577835 & 7155653 \\
\hline SSK işveren hissesi & 182161 & 182161 & 220414 & 65578 & 0 & 714698 & 1429393 \\
\hline İşsizlik sigorta işveren payı & 18009 & 18009 & 21790 & 6483 & 0 & 70656 & 141311 \\
\hline Kıdem-İhbar tazminatları & 17063 & 17063 & 20646 & 6143 & 0 & 66945 & 133890 \\
\hline Faturalı yemek giderleri & 87522 & 87522 & 105902 & 31508 & 0 & 343389 & 686776 \\
\hline Personel sağlık giderleri & 1667 & 1667 & 2017 & 600 & 0 & 6540 & 13081 \\
\hline Personel kiyafet gideri & 34300 & 34300 & 41503 & 12348 & 0 & 134574 & 269147 \\
\hline Eğitim ve seminerler & 1422 & 1422 & 1721 & 512 & 0 & 5580 & 11160 \\
\hline Akaryakıt & 279797 & 279797 & 338554 & 100727 & 0 & 1097770 & 0 \\
\hline Yedek parça & 2388 & 2388 & 2889 & 860 & 0 & 9369 & 0 \\
\hline Araç sarf malzeme & 8060 & 8060 & 9753 & 2902 & 0 & 31623 & 0 \\
\hline Yağlar & 17576 & 17576 & 21267 & 6328 & 0 & 68960 & 0 \\
\hline Yeni lastik - tamirli lastik & 26628 & 26628 & 32220 & 9586 & 0 & 104474 & 0 \\
\hline Malzemeli işçilik & 274865 & 274865 & 332586 & 98951 & 0 & 1078418 & 0 \\
\hline Araç kasko-trafik sigortası giderleri & 108900 & 108900 & 131769 & 39204 & 0 & 427264 & 0 \\
\hline Araç MTV giderleri & 7058 & 7058 & 8541 & 2541 & 0 & 27693 & 0 \\
\hline Araç muayene ve egzoz giderleri & 38640 & 38640 & 46754 & 13910 & 0 & 151602 & 0 \\
\hline Kira giderleri & 368160 & 368160 & 445473 & 132537 & 0 & 1444458 & 2888910 \\
\hline Elektrik-su-yakıt giderleri & 101532 & 101532 & 122854 & 36551 & 0 & 398356 & 796710 \\
\hline Diğer yönetim giderleri & 572461 & 572461 & 692677 & 206085 & 0 & 2246022 & 4492034 \\
\hline Amortismanlar & 201536 & 201536 & 243859 & 72553 & 0 & 790718 & 0 \\
\hline \multicolumn{8}{|l|}{ Gayri Resmi Sistem Gider Kalemleri } \\
\hline Personel giderleri & 3118814 & 0 & 0 & 0 & 3234968 & 1672550 & 0 \\
\hline Malzeme giderleri & 85000 & 0 & 0 & 0 & 85000 & 40000 & 0 \\
\hline Kira giderleri & 300000 & 0 & 0 & 0 & 300000 & 150000 & 0 \\
\hline Toplam Giderler & 6765468 & 3261654 & 3946597 & 1174193 & 3619968 & 14659496 & 18018065 \\
\hline
\end{tabular}




\begin{tabular}{|c|c|c|c|c|c|c|c|}
\hline Performans İndikatörü & MS & S1 & S2 & S3 & S4 & S5 & S6 \\
\hline İş kazaları & 0 & 1 & 0,5 & 0,5 & 0 & 0,5 & 1 \\
\hline İş hastalıklarına yakalanma riski & 0 & 1 & 0,5 & 0,5 & 0 & 0,5 & 1 \\
\hline Güvenlik ve sağlık farkındalığ1 & 0 & 0,5 & 0,5 & 0,5 & 0 & 0,5 & 1 \\
\hline Sistemin güvenlik riski & 0 & 1 & 1 & 1 & 0 & 0,5 & 1 \\
\hline İş sağlığı ve güvenliği eğitimleri & 0 & 1 & 1 & 1 & 0 & 1 & 1 \\
\hline Uygun iş ekipmanlarıyla çalışma & 0 & 1 & 1 & 1 & 0 & 0,5 & 1 \\
\hline Yerel halkın sağlık ve güvenlik koşulları & 0 & 1 & 1 & 1 & 0 & 0,5 & 1 \\
\hline Yerel halkın emniyetli yaşam koşulları & 0 & 1 & 1 & 1 & 0 & 1 & 1 \\
\hline İş memnuniyeti & 0,5 & 0,5 & 1 & 1 & 0,5 & 1 & 1 \\
\hline Yasal çalışma saatlerine uyumluluk & 0 & 1 & 1 & 1 & 0 & 1 & 1 \\
\hline Gece çalışması & 0 & 1 & 1 & 1 & 0 & 1 & 1 \\
\hline Açlık sınırında maaş alan çalışanların varlığ & 0 & 1 & 1 & 1 & 0 & 1 & 1 \\
\hline Düzenli ödemeler & 0,5 & 1 & 1 & 1 & 0,5 & 1 & 1 \\
\hline Yasal iş sözleşmesi & 0 & 1 & 1 & 1 & 0 & 1 & 1 \\
\hline Emeklilik hakları & 0 & 1 & 1 & 1 & 0 & 1 & 1 \\
\hline Sosyal güvenlik hakları & 0 & 1 & 1 & 1 & 0 & 1 & 1 \\
\hline Ĕgitim programları & 0 & 1 & 1 & 1 & 0 & 1 & 1 \\
\hline Zorunlu çalıştırma & 0,5 & 1 & 1 & 1 & 0,5 & 1 & 1 \\
\hline Çocuk işçi çalıştırma & 0 & 1 & 1 & 1 & 0 & 1 & 1 \\
\hline Toplu sözleşme ve grev haklarının varlığı & 0 & 1 & 1 & 1 & 0 & 1 & 1 \\
\hline Siyasi, bölgesel ve dini ayrımcılık & 0 & 0,5 & 0,5 & 0,5 & 0 & 0,5 & 1 \\
\hline İşs sahası yaratma durumu & 1 & 0 & 0 & 0 & 1 & 1 & 1 \\
\hline İş kaybı yaratma durumu & 1 & 0 & 0 & 0 & 1 & 1 & 1 \\
\hline Sistemi destekleyen kişi sayısı & 0,5 & 0 & 0 & 0 & 0,5 & 0,5 & 1 \\
\hline Belirlenen şikâyet sayıları & 1 & 0 & 1 & 0 & 1 & 0,5 & 1 \\
\hline Sistemin ekonomik gelişime katkısı & 1 & 0 & 0 & 0 & 1 & 1 & 1 \\
\hline
\end{tabular}




\begin{tabular}{|c|c|c|c|c|c|c|c|}
\hline & & & & & & & \\
\hline & & & & & & & \\
\hline Toplanan geri dönüştürülebilir atık miktarı (ton/yıl) & 33451,12 & 4262,98 & 5158,2 & 1534,67 & 32349,68 & 33451,12 & 33451,12 \\
\hline Ayrıştırılan geri dönüştürülebilir atık miktarı (ton/yıl) & 32676,17 & 3944,25 & 4929,29 & 1438,11 & 32349,68 & 33396,05 & 33396,05 \\
\hline Faydalı yan ürün miktarı (ton/yıl) & 27715,25 & 3378,48 & 3614,2 & 1229,01 & 27374,68 & 28295,48 & 28295,48 \\
\hline Artık miktarı (ton/yıl) & 5735,87 & 884,5 & 1543,98 & 305,67 & 4975,01 & 5155,64 & 5155,64 \\
\hline Kullanılan toplama materyali miktarı (birim/ton) & 910566,05 & 1363460,47 & 781,2 & 252 & 850 & 883,6 & 2896,59 \\
\hline Yakıt tüketim miktarı (kg/yıl) & 315732,27 & 152441,90 & 159314,83 & 126554,90 & 267590,64 & 286137,71 & 393216,77 \\
\hline Elektrik tüketim miktarı $(\mathrm{kWh} / \mathrm{y} 1 \mathrm{l})$ & 2407941,27 & 255912,06 & 261126,51 & 90402,12 & 2408051,60 & 2434907,34 & 2434907,34 \\
\hline Su tüketim miktarı $\left(\mathrm{m}^{3} / \mathrm{y} 1 \mathrm{l}\right)$ & 13100,32 & 1687,73 & 2042,18 & 607,59 & 12648,73 & 13100,32 & 13100,32 \\
\hline Termal enerji tüketim miktarı (MJ/yıl) & 11659817,68 & 5787929,39 & 6702868,02 & 1941390,57 & 6783178,29 & 11810764,78 & 11810764,78 \\
\hline
\end{tabular}

Ek 4. Ambalaj atığ 1 toplama miktarları

\begin{tabular}{|c|c|c|c|c|c|c|c|}
\hline & MS & S1 & S2 & S3 & S4 & S5 & S6 \\
\hline Karışık Ambalaj (ton/yıl) & 3161,54 & - & 3825,46 & 1138,15 & - & - & - \\
\hline Çöple Karışık Ambalaj (ton/yıl) & 29188,15 & - & - & - & 32349,68 & 32349,68 & 32349,68 \\
\hline Kâğ1t-Karton (ton/yıl) & - & 2662,35 & - & - & - & - & - \\
\hline Metal-Plastik (ton/y1l) & - & 499,19 & - & - & - & - & - \\
\hline Cam (ton/y1l) & 1101,44 & 1101,44 & 3825,46 & 396,52 & - & 1101,44 & 1101,44 \\
\hline
\end{tabular}

